This article was downloaded by: [Lulea University of Technology]

On: 14 October 2011, At: 06:12

Publisher: Routledge

Informa Ltd Registered in England and Wales Registered Number: 1072954 Registered

office: Mortimer House, 37-41 Mortimer Street, London W1T 3J H, UK

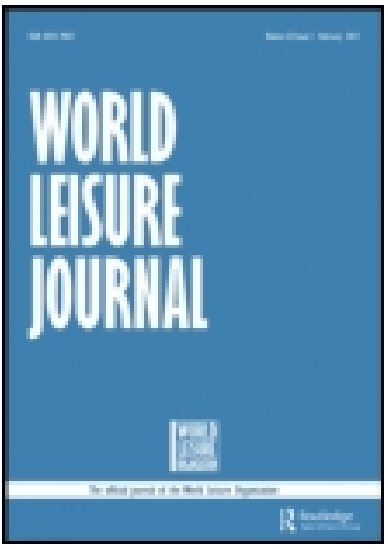

\author{
World Leisure J ournal \\ Publication details, including instructions for authors and \\ subscription information: \\ http:// www.tandfonline.com/loi/ rwle20
}

\title{
The riding school as a site for gender identity construction among Swedish teenage girls
}

\author{
Lena Forsberg ${ }^{a} \&$ Ulla Tebelius ${ }^{b}$ \\ a Department of Business Administration and Social Sciences, \\ Luleå University of Technology, SE-971 87, Luleå, Sweden \\ b School of Health and Society, University of Halmstad, Box 823, \\ 30118, Halmstad, Sweden
}

Available online: 18 Mar 2011

To cite this article: Lena Forsberg \& Ulla Tebelius (2011): The riding school as a site for gender identity construction among Swedish teenage girls, World Leisure J ournal, 53:1, 42-56

To link to this article: http:// dx.doi.org/ 10.1080/ 04419057.2011.552218

\section{PLEASE SCROLL DOWN FOR ARTICLE}

Full terms and conditions of use: http://www.tandfonline.com/page/terms-andconditions

This article may be used for research, teaching, and private study purposes. Any substantial or systematic reproduction, redistribution, reselling, loan, sub-licensing, systematic supply, or distribution in any form to anyone is expressly forbidden.

The publisher does not give any warranty express or implied or make any representation that the contents will be complete or accurate or up to date. The accuracy of any instructions, formulae, and drug doses should be independently verified with primary sources. The publisher shall not be liable for any loss, actions, claims, proceedings, demand, or costs or damages whatsoever or howsoever caused arising directly or indirectly in connection with or arising out of the use of this material. 


\title{
RESEARCH PAPER
}

\section{The riding school as a site for gender identity construction among Swedish teenage girls}

\author{
Lena Forsberg $^{\mathrm{a} *}$ and Ulla Tebelius ${ }^{\mathrm{b}}$ \\ ${ }^{a}$ Department of Business Administration and Social Sciences, Luleå University of Technology, \\ SE-971 87 Luleå, Sweden; ${ }^{b}$ School of Health and Society, University of Halmstad, Box 823, \\ 30118 Halmstad, Sweden
}

\begin{abstract}
This paper is based on observations and interviews with six teenage girls (age 14-16) currently highly active in a Swedish riding school. Riding is one of the most popular sporting activities among girls in Sweden and riding schools receive financial support from the government to make riding available to everyone. The aim of this paper is to explore how teenage girls construct their gender identity at the stable through the handling of horses and related work in their leisure time. Theoretically, we employ Butler's (1999) theory of identity, based on social constructivism. The relationships with the horses, the hard work, the unexpected challenges, as well as the friendships among the girls, were found to be essential elements of the stable experience. At the stable, the girls learned to take action, handle risks and take the lead. This created an alternative way of enacting themselves as young females, resulting in an identity based on being independent, competent and powerful. As such, the riding school represents a developmental space where teenage girls can prepare themselves for their future, independent, lives.
\end{abstract}

Keywords: girls; leisure; identity; riding; social constructivism

\section{Introduction}

This paper reports on research conducted on six teenage girls in a Swedish riding school. In the area of sport and leisure, there is a considerable body of research that has focused on the barriers to and constraints on participation experienced by women (Crawford \& Godbey, 1987; Gilligan, 1982; Henderson \& Bialeschki, 1993; Jackson, 1993; Little, 2002; Wright et al., 1998). For instance, Hendersen (1989) and Deem (1986) have problematised the definition of leisure and its male bias. They have investigated women's leisure experiences and made them visible by relating women's activities - or lack of activities - to the wider contexts of their lives. Hendersen (1989), Deem (1986), and others, have shown that it is important to explore social, political and economic factors that underlie the politics of leisure. By focusing on riding, the most popular sport for girls in Sweden, we hope to make a contribution to the research on leisure and the construction of femininity. The aim in this paper is to explore how teenage girls, active at a stable, experience their leisure activity in relation to the construction of a gender identity. 


\section{Research on women and sport}

A number of authors explore why women and girls decide to be active in "nonfeminine" leisure in spite of the constraints on so doing. Auster (2001), for example, studied 453 women motorcyclists. She points to the importance of being in social environments that provide perceived rewards which outweigh the effects of the expected constraints. To make non-traditional leisure choices, or choose male activities, women must be exposed to a social environment that provides both awareness of and support for the choices they make.

Murray and Howat (2009) conducted interviews with 40 female rugby players from South Australia to examine their motives for initially starting - and for continuing - to play rugby. The reasons given by these women were that they knew other players, or had families which were supportive and involved in the sport. Hence, the social element was a key motivator. In a further example, Park and Wright (2000) show that girls were frequently discouraged from participating in contact sports because appearance, grace and poise (traditional "feminine" qualities), rather than exhibiting aggression and power (traditional "masculine" qualities), were seen as appropriate for girls involved in sport.

More generally, in a North American context, Freysinger and Flannery (1992) discuss leisure as a site of women's empowerment and resistance. In the case of the women in their study, leisure was seen as a way to develop and maintain friendships, and an opportunity for self-determination and freedom in their choices of activities. These women gained feelings of capability, competence and confidence, which helped them express themselves in new or different ways.

\section{Horse riding in Sweden}

Sweden has the highest number of horses per capita in Europe, and thus many riders. A vast majority of riders - 85\% compared with the European average of $75 \%$ - are female (Liljestolpe, 2009). In Sweden, organised leisure activities for young people are supported by the government as a way to promote health and citizenship (Lindström, 2009; Ståhlberg, 1999). Since the middle of the twentieth century, the sports movement has received considerable funding from the government (Lindström, 2006). This funding has been important for the growth of the Swedish riding movement, where horseback riding is a popular leisure activity, especially on the part of girls reaching their teens. About 200,000 Swedes are members of riding schools, of whom $50 \%$ are younger than 25 years of age. The vast majority are female (SOU, 2000). About $70 \%$ of riding schools are owned by municipalities/local authorities.

The structural organisation of Swedish riding has given the sport a unique character, in contrast to several other countries where riding is mainly the prerogative of the wealthy. Horse riding has its roots in activities related to the military, agriculture and transport, a fact which is reflected in the way the leisure activity is administered. Male concepts, such as hierarchy, orderliness and discipline, are still fundamental parts of riding (Raber \& Tucker, 2005). Thus, an interesting characteristic of today's stables in Sweden is the clear dominance of male structures and the equally clear preponderance of female actors (Forsberg \& Tebelius, 2005). This leads to the question: in what ways do a male-structured setting and a dominance of female actors contribute to gender performances? The combination of 
a male structure, a relationship with a horse and a female-dominated setting might have consequences for girls' self-image.

Kanter (1977) showed that the dominance of one sex within a work context has consequences for the individual's opportunities. Unlike Kanter, our area of interest is teenage girls in a leisure, not work, setting. We want to explore the opportunities that this special setting may offer the riding girls in terms of constructing a "doing" gender.

The remainder of this paper is organised as follows. First, we present a theoretical framework and a review of earlier empirical research on the subject. We then present our methodology, describing how we collected and analysed our material. In the results section, we present our empirical material under three central themes that emerged from the analysis. In the final section, we discuss the findings and implications and present our conclusions.

\section{Theoretical framework}

We use social constructivism as a meta-perspective and, theoretically, we employ Butler's (1999) work on identity development as a central reference point. From this perspective, the self is seen as constructed within a specific context where values are an important component. For Butler, the human being is a creature to whom objects have meaning, and the meaning s/he gives to the objects contributes to deciding who $\mathrm{s} / \mathrm{he}$ is. This process of creating meaning is normative within what Butler calls the "heterosexual matrix". The matrix includes both how to do gender and how to become a woman or a man. The norms make traces in our bodies - what Butler calls materiality - and this process is dependent on context, time and place. The image individuals have of themselves is a result of their reflections on their actions and of their position within a specific context (Stern \& Ammanit, 1994; Weiss, 1999). By continuously reflecting on their life history, while integrating their emotional, cognitive and physical development, individuals construct and reconstruct their gendered selves. This is done within a special discourse through negotiations with others. In this process, a personal style is developed in dialogue with others and in conjunction with the person's value orientation: "persons only become intelligible through becoming gendered in conformity with recognizable standards of gender intelligibility" (Butler, 1999, p. 16).

Identities are built on strong values, which are created by co-corporative agreements as to what constitutes "good things". An example of this is provided by Skeggs' (1997) study of working-class women, where women's struggles were mostly aimed at defending the collective quality of being "respectable". Identity does not reflect an objective social position, nor is it an essential category, a fixed core. Identity is something ongoing, which an individual sets about reproducing as a response to social situations, using the available system of representation. The more time people invest in a certain culture and fellowship, the more this will influence their identities (Gordon, 2002). In sport, teenage girls are trained to be aware of the significance of the function and performance of their bodies (Tebelius, 2009). This may result in differentiated knowledge of their competence in sport, and an ability to reflect on the capability of their bodies. If riding activity is important for teenage girls, the experiences they gain may play a role in the creation of their identities. Both girls and boys are expected to develop self-confidence and independence in their 
youth. For girls, this correlates with social notions of how women are and should be (Tebelius, 1999). Being seen as feminine is important for the teenage girl, who is in the process of forming her position as an adult woman (Tebelius, 2001). Earlier studies have shown that girls become invisible in environments containing both girls and boys (Bäckström, 2005; Gilligan, Lyons, \& Hanmer, 1990), which suggests that whether the environment is gender heterogeneous or homogeneous is important. We ask the question: how does a social milieu like the riding school - run by women and girls - affect girls in their process of creating identities?

\section{Previous research on the leisure pursuits of teenage girls}

McRobbie and Garbor (1976) and James (2001) showed that teenage girls strive to find places for recreation where they can feel safe and self-content. They found that, for many female youngsters in Europe, North America and Australia, one such place is the bedroom. James (2001) showed that the girls in her Australian study looked upon their bedrooms as a place to feel secure, where they could "be themselves". Bedrooms were also sites of resistance against the less "girl-friendly" public rooms that were offered in school and the society in which they lived. The girls were concerned about how to appear in front of others and they wanted to be able to control their "audience". Inspired by these findings, we consider whether the riding stable offers another space where teenage girls may "resist" girl-unfriendly places, but also develop and practise important aspects of "female" gender, collectively and supportively.

There are very few studies of girls' riding as a leisure activity. Redelius (2002) studied different sports and found that riding activities are hierarchically organised, regulated by strict rules and guarded by adults. The instructors regarded experience of competition among their students as highly valuable. Larsson (2006) studied boys who were active in riding schools and found that they generally favoured competing. She also noted that these boys could develop at the stable in relational ways, for instance by being empathic and displaying emotions, not condoned for boys in other environments. When looking for boys and men to study, Larsson did not find them in the municipally-owned riding schools. Most boys and men interested in horses enjoy a family heritage where they have access to privately owned horses. Their riding practice takes place within family settings, with the main aim being to qualify for important competitions where they dominate nationally and internationally.

In a Finnish study, Kallioniemi (1997) interviewed riding girls (11-12 years old) and asked them about their motives for riding. Their responses indicated that they had dreamed of horses since they were small and that their devotion to horses went together with an overall love of animals in general. Tolonen (1992) shows that girls learn a feminine care-giving identity at the stable. According to Tolonen, the girls idealise their sacrifices. The stable girl worships the horse, but at the same time she wants to own and control it. Through her devoted care the girl learns how to interpret the animal, and when the horse responds, she feels appreciated. In line with this, Nikku (2005) identifies two sides of the stable girl, one caring side and one side concerned with power and control, both of which are needed to handle horses.

In a Danish study, Rostgård (2002) found three different groups of riding girls, namely: "horse dreaming girls", "riding girls" and "stable girls". By means of these labels, Rostgård wanted to show that the girls' relationship to horses differed and 
that they had different motives for being at the stable. Dreaming girls are fascinated by horses but do not ride themselves. Riding girls are active riders a few times a week but have other leisure activities too. Stable girls are those who spend almost all of their spare time at the stable - not only riding - together with the horses and their friends. According to Rostgård, this is the group most affected by the special atmosphere of the stable. It operates within a tradition of masculine values and activities, which require physical strength, authority and practical skills. This makes riding settings particularly interesting in terms of theories of gender formation. The cultural setting of the stable and the fact that the participants are mostly female, may offer a milieu wherein gender formations are "stretched". True, the girls develop relationships with the horses shaped by romantic images from films and books; and in relationships within the stable, emotions and romance form the prerequisites for the girls' identity construction. So too, however, do hard physical work and bodily control make a contribution to identity. Through accepting such values, the girls can "do" gender, in Butler's sense, in a way that differs from more stereotypical ways of performing gender. At the stable, the girls can choose subject positions that differ from traditional gender expectations.

\section{Methodology}

In line with Skeggs (1997), we wanted to gain an insight into people's own experiences of the social world in which they live. Six teenage girls (age 14-16), all highly active in a single riding school, are the source of empirical material in this study. They spent much of their time together with other people engaged in activities related to the horses - not only riding - and taking responsibility for other activities at the riding school. All of the girls spent at least 20 hours a week at the stable and thus belong to the category of "stable girls" in Rostgård's (2002) terminology.

\section{Gathering information}

The first author spent more than a month following the girls several times a week when they were at the stable. During this month, time was spent on observations and on formal and informal interviews. Approximately one year after the first contact, the first author met all of the girls one-to-one for a follow-up interview.

The observations were made during a continuous period of five weeks, on 14 occasions in total, varying in length from one to seven hours. The girls were observed when they spent time at the stable, either as a group or separately. How they acted and their relationships with the horses and other girls at the stable were recorded in field notes. Additionally, notes on how the stable was organised and other characteristics of the stable environment were taken. The observations gave us information about the context and the stable culture, and more importantly, how the girls actually behaved within this context and what language they used when acting in the stable.

During the first data collection period, the interviews with the girls were mainly informal and related to asking about everyday actions, conversations and experiences when they were at the stable. Every Tuesday, when they had organised riding practice, all the girls were together and spent a considerable time (usually one or two hours) talking about what they had recently experienced. The girls talked about 
themselves, riding and the others in the stable, what it meant to be at the stable and what they had experienced in the realm of the stable. The follow-up interviews with each of the six girls provided an opportunity to probe further into the themes that had emerged from observations and earlier interviews. These (more formal) interviews were a way of both validating our initial findings and getting each girl to provide individual reflections on their lives at the stable. All follow-up interviews were conducted in the riding school cafeteria, in a calm undisturbed atmosphere.

\title{
Ethical considerations
}

The parents and the participants were given full information about the purpose of the study. The girls were told that participation was at their own free will and that they could withdraw at any time, if they wanted to. The parents gave written permission for the girls to take part in the study. In the text, the girls are referred to by pseudonyms.

\begin{abstract}
Analysis
Altogether, the meetings with informants and the field notes resulted in about 350 pages of empirical material. To understand this material, we used content analyses (Kohlbacher, 2006); this means that we looked for analytic units in the girls' statements, especially what conditions and experiences they referred to. In the observations, we looked for frequently emerging and critical incidents. These were then compared with how the girls talked about the same practices. We followed the step model outlined by Mayring (2000), going from theoretically-based categories of analysis, working through the texts and then formulating the final categories or themes. Our content analysis resulted in the following themes:
\end{abstract}

(1) Handling and caring for the horse. This theme emerges as the most prominent when the girls talked about their life at the stable.

(2) Hard work and getting yourself dirty. This theme relates to what is physically demanded from the girls in order to ensure the wellbeing of the horses and keep the riding school in order.

(3) A sanctuary from social pressure to conform - forming a "non-bothering gang". The final theme concerns the way the girls perceive themselves and cope with aspects of developing their gender identity.

\section{How the girls positioned themselves at the stable}

In this section, we present the three themes emerging from the empirical material. We quote some of the girls as a way of illustrating how they expressed themselves. But first we will provide some background information about the six girls.

All of the girls are Swedes living in privately-owned homes, with both parents present. They are successful in school. All of them have mothers who are interested in horses and (with one exception) ride horses themselves. This indicates that riding as a leisure activity on the part of these girls follows the general pattern in Sweden, where sports are dominated by high-achieving, white, middle-class people (Engström, 1999). According to Lareau (2003) and many other researchers (e.g. Ambjörnsson, 2004), belonging to the middle class often means that the parents impose values such 
as orderliness, loyalty and initiative on their children. The relationship between gender and class is complex, and both have an impact on the way gender is situationally constructed.

\section{Theme 1: handling and caring for the horse}

The ability to handle a horse is the most important skill at the stable because of the animal's character. The horse is a sensitive, expressive animal, which, for survival, is ready to escape as the result of any disturbance or following the signal of the herd leader. That is why it is necessary for the rider to take control, since the situation may otherwise become dangerous. If something unexpected happens, such as an unattached horse running freely, then the girls must be ready to take action and handle the situation. As Butler (2004) states, gender norms are formed in connection and actions depend on context. The special contact with the horses makes traces in the girls' bodies and becomes the most important part of the subject position. This is manifested through different skills, among which communication with the horse is the most important.

Communication. The girls, who were experienced and managed to control the horses, could articulate what was important in the relationship. Often they used the phrase "to be firm" when they talked about a horse, which meant, as Moa expressed it, that "you need to show clearly what you want the horse to do or what you have in mind". Domesticating a large, and partly still wild, horse, on the part of a small girl weighing 40 kilograms, is not primarily a matter of strength but of communication. Moa explained how she tries to develop a relationship of trust instead of forcing solutions on the horse:

Moa: He was very doubtful of me ... I was not allowed to pat him on the face ... and I fell off when riding him, when he panicked as a rabbit jumped near him, and after that he ran away and was beyond contact... He can be very sensitive.

Interviewer: How did you reach him? What did you do?

Moa: Our relationship is now stronger; we have spent a lot of time together, and he even neighs when I come. ... I have given him time to accept me.

This example indicates that to get the horse to co-operate, trust is needed and one needs to communicate with the horse and listen to its responses. In related situations, the girls recognised that their ability to communicate and relate to the horse became proof of their competence. The girls all agreed that becoming capable of commanding the horse with subtle signals also led to a higher position in the social sphere of the stable. The girls were able to perceive and understand when the horse was satisfied, and seemed to enjoy the interaction. Julia told us that when she managed to communicate with a horse called "Nadja", who is known for behaving unpredictably, this made the other girls acknowledge her as competent and someone worth listening to.

The fact that there is an animal involved makes riding different from other leisure activities. "You can't talk to a hockey stick," Sandra said, pointing to the communicative aspect needed when handling a horse. This was the factor that caused the girls to spend a lot of time at the stable. They communicated verbally, through their body language and in the way they behaved at the stable. Their 
behaviours were distinct, with no quick movements, and they did not scream at each other or at the horses.

Riding skill. Communication with the horse was central because it influenced how the riders succeeded in handling the horse when riding. The most embarrassing thing for the girls was if the horse did not co-operate or obey. Sometimes, as Fia said, the horse could feel "stiff as a stick". At such times, the horse did not want to co-operate at all, but, said Fia, "that is a part of the game". The challenge was to build trust and convince the horse that one could take command. The ultimate indication of this was when the girls competed with the horses. The highest rank in the group was given to the person who best managed to ride the horse on a track. This meant that the girls could invest in that knowledge and skill to get a subject position, to be a person who manages the horse in a proper way, especially in a competitive situation. As all of the girls took part in competitions, this was an important goal. The field notes recorded at an equestrian sport session indicate that the girls were exhilarated and excited.

The girls had to learn how to handle the interplay with the horse in all types of situation, as it could react differently to calm or noisy, crowded settings. The girls' self-confidence grew when they developed more knowledge of, and competence in, not only riding but also how to attend to the wellbeing of the horse. Maria claimed the girls were aware that the interplay between themselves and the horses was important to evaluate both their own effort and competence, and the horses' capacities. This had to be seen in relation to the fact that the reality for a riding school horse was adapting to different riders every day. The most valued person, according to Erika, was the one who managed to handle "the impossible Joker", a horse that usually did not want to compete and jump the hurdles on the track. To win was great fun and a goal, but the girls' own skill was more focused. They were aware that their performance was related to how well they could manage the horse on the track.

Taking the lead. Handling potentially dangerous horses forced the girls to be resolute, to take control and to take action. It was important not to give up when they were faced with problems, according to Fia, who recounted a common situation when a horse needed to be moved but did not want to obey. In such a situation, the girls needed to be both patient and clear and often they developed creative solutions to find the best methods suitable for the horse. Sometimes they were forced to handle difficult situations without hesitating. Erika reported an occasion when she had to give her horse an injection without assistance. Even though she had never done anything like that before, it was self-evident that she would manage since it was important for her horse's wellbeing. Experiences like these contributed to the picture the girls had of themselves as brave, efficient and ready to take action in unexpected situations. However, the focus on what was best for the horses permeated the girls' relationships with them. It was through the relationship with the horse, and the clear link between actions and consequences, that the riders' efforts became meaningful.

Concern for the horse. Our study, like other studies, has shown that most of the girls who start riding have a love of animals in general. That is their primary reason for starting with horses. In that sense, it is a confirmatory activity regarding gender, and the stable can be a place for women and girls to "possess their own space". However, 
to take care of the horses was a matter of choice and not of sacrifice. The care they gave the horses was a manifestation of the girls' competence to determine what the horses needed, on which their legitimacy at the stable rested. Taking care of horses was a matter of self-determination and freedom to do what the girls wanted to do. This is consistent with the views of the women in Freysinger and Flannery's (1992) study.

Most of the time the girls spent at the stable had to do with the wellbeing of the horses. Their feelings of love for the horses were great and, hence, Maria declared, taking care of the horses was not interpreted as self-sacrifice. Most of the horses were owned by the riding school and there were staff working at the stable and looking after the horses. However, each of the girls, who spent a lot of time at the stable, had a tendency to consider at least one of the horses as their special responsibility. During a conversation involving all of the girls, they indicated that their favourite horses could "die" if they did not take care of them. Even when sick in bed they had to attend to their favourite horse, they explained. Still, the girls were aware of sometimes exaggerating the care and grooming required. Then they would often make ironic comments, as when Moa said: "we could make a wig out of the hair from the horse's mane and give it to someone bald-headed." Their preparedness to take care of the horses was an important aspect, but the girls did it under their own conditions. They knew that they could get help from other girls in the stable and that the riding school was looking after the horses as well. However, they chose to provide care. The horses' wellbeing was important, yet the girls had to balance being diligent and attending to other demands in their lives.

Being capable. By attending consistently to the horses and learning to ride and control them, the girls had established a subject position of being capable and responsible within the norms of behaviour that were valued at the stable. This had to do with their ability to rely on adequate competence and legitimate judgements concerning what was best for the horses. A way of accentuating this position was for the girls to distance themselves from those who, in their opinion, did not have the same attitude toward the horses. The girls were confident that they knew and understood the needs of the horses as well as or better than most other people at the stable. This could be seen in the notes which they had attached here and there at the stable to communicate its rules and norms to visitors. Some of the notes were written as a message from a certain horse, saying that it wanted a specific blanket or a special treatment. The reason for this form of communication was to secure the wellbeing of the horses. The girls saw themselves as ambassadors for the horses - that was why they wrote the notes in this way.

\section{Theme 2: hard work and getting yourself dirty}

Life in the stable, most of the time, involves hard labour. Every day, on several occasions, the horses need to be cared for, fed, and groomed. Apart from the horses, the equipment, like the snaffle and the saddle, also have to be looked after. When pressed for time, the girls sometimes brought the equipment home and finished their work late in the evening. Moa emphasised that joining a stable meant more than getting involved in other sports: 
It is a place to feel meaning. If I didn't have the stable I probably would lie on the sofa watching TV. Here, my actions are needed and it has given me self-confidence. I have solved situations by myself. It is me who needs to take care of everything after the riding session. ... I am involved in estimating things that need to be done at the riding school. It is fun to work on the idea of a new riding arena and so on.

The girls were devoted and felt that their physical work was meaningful, as it had to do with the wellbeing of the horses.

A condition of being allowed to ride. The girls' engagement in physical work at the stable also had to do with their wish to develop their riding skills. So, even if the work was voluntary, it was a condition of being allowed to ride. When they wanted to progress in their riding skills, with the possibility of competing, they also had to be willing to undertake work. At the stable, diligence and preparedness to act are rewarded. By being hard working, the girls were acknowledged as being trustworthy and hence received more opportunities to ride. The girls also accepted the hard work, because it was a way to develop their professional skills. Julia reported that, in her daily work at the stable, she learned to be proactive in anticipating problems:

If you don't close the front doors of the stable and the water pipes freeze and break, then Adam [the janitor] will come down on you! And even if I was afraid of forgetting it, today I close the door, I never leave a door open. ... I never leave the pitchfork in the hay ... but the reason is because somebody has explained the importance of it!

Appearance. Over time, the ability to do hard and sometimes quite dirty work became part of the girls' self-understanding, and by doing it they claimed that their sense of competency increased. Being afraid of breaking their fingernails or resisting wearing comfortable, warm but unattractive clothing were out of the question. "If they did not accept the unglamorous characteristics of this world then they were in the wrong place," Erica said, in a proud voice. Nevertheless, the girls had some doubts about whether adapting to the confines of working all the time was worthwhile when they were not guaranteed free riding lessons as compensation. Being ambitious, diligent and loyal was a way to get attention but, at the same time, the girls did not want to feel that they were being exploited.

Doing hard physical work at the stable meant that the girls got dirty and messy, but in their striving to fulfil the tasks, they did not mind. "The stable is the only place where you don't need to think about how you look," Moa said, covering her face a bit more with her cap. The cap was a sign of the girls not bothering about how they looked when they did manual work at the stable and took care of the horses. They did not care if their clothes were dirty, their hair uncombed, or if they went straight from bed to feeding the horses. However, on some occasions, clothing was important. Maria explained: "I do like to wear smart clothes when competing at the stable; not necessarily an expensive outfit, but it's still nice to be good looking when you compete." When they were taking part in competitions, the girls wanted to look proper; hence they wore club jackets. At important training sessions, they wore clothes that did not impede movement.

The culture at the stable was formed by hard work, responsibility and challenges, all of which the girls were expected to manage. The physical work and not caring about their looks became part of their identity creation. In practice, when they 
handled strenuous and critical events, the girls identified themselves as brave, enterprising and responsible, while their appearance was only important in relation to competitions and sometimes in riding lessons with an external riding instructor.

Theme 3: a sanctuary from social pressure to conform - forming a "non-bothering gang"

As the riding school is populated mostly by females, it is an arena in which girls can be together without many boys being present. They are not expected to meet stereotypical body ideals. It meant something special for them that the stable was dominated by girls with the same interest. As they knew each other well, they were in control of the audience (cf. James, 2001). Given their devotion to stable life, consideration of how they might appear to others was not an issue for them.

The girls were great friends and encouraged one another at the same time as they invested in their individual positions. When some of them did something brave and skilful, the others became inspired. Maria expressed her feelings about the friendships at the riding school as being "half the fun" of the stable experience.

The girls described themselves as different from other girls outside the stable. In school it was important to have good-looking clothes, a nice appearance, and to take part in social activities. The girls indicated that they did not consider themselves part of the popular group of girls in school and, Erika declared, they had deliberately chosen this way of displaying themselves. They experienced themselves as being more mature than their schoolmates. As an example, Julia explained that she would rather spend time at the stable on a Friday evening and learn some more things, than go to parties where many other girls of her age spend a lot of time. To become skilled in riding was important and the girls knew how to set goals and work purposefully to reach them. They enjoyed the feeling that horses need care and training every day of the week and that it is important to take up that responsibility. The concern was not only for themselves, to improve their performance; maintaining and improving the horses' wellbeing and skilfulness was also part of their goals.

The girls had created a collective, independent style and did not bother about being "cool" and having frequent parties like the popular girls at school. Together they felt strong. Talking about the group they belonged to, Fia explained that they call themselves the "non-bothering gang". Their engagement at the stable and with the horses seemed to enhance resistance to many of the demands the girls were exposed to in their wider daily lives. Through their friendships and practice at the stable, the girls could articulate different gender positions. These positions involved feelings of independence and competence, which gave them strength to act and perform in an autonomous way outside the stable as well. Erika reflected that "horse girls" like her often felt satisfied to be engaged in something that was more important than investing in new clothes and lots of make-up. She felt empowered to be in a fellowship that showed that there were other ways to express oneself. Being a part of the group of girls from the stable was aligned with the values Erika held as important.

\section{Discussion and conclusions}

Our analysis is based on a social constructivist perspective, which challenges the idea of a true reality (Winther-Jorgensen \& Philips, 1999) and sees knowledge as a 
product of social processes. For research purposes, this requires adopting a critical attitude and recognising the world as a product of the way our informants and we as researchers categorise the world.

It seems clear that the stable girls we have studied are involved in a leisure activity that has an impact on the way they construct their identities. There are a number of distinct aspects of the activities at the stable that emerge in the three themes. These are: (1) the strong relationship with the horse; (2) the girls' focus on improving their riding ability; (3) the hard and dirty work; (4) the unexpected challenges; and (5) the strong friendship among the girls. Together, these aspects result in the stable being a potentially powerful developmental ground for teenage girls.

The first two aspects seem central in creating meaning from the girls' leisure interest and also indicate power positions at the stable. It is the interaction with the horses that allows the girls to develop and position themselves as leaders; they build their competence to handle and command the animals. These experiences affected their identity-construction process and materialised in the way they talked about and carried out their responsibilities. In handling the horses, the girls performed traditional female tasks of taking care and giving love, but, contrary to Tolonen's (1992) findings, these girls were more instrumental, as they considered care and love to be important not only for the wellbeing of the horses but also to becoming accomplished riders.

The hard, dirty and sometimes dangerous work outlined in aspects (3) and (4) was not a primary reason for the girls' leisure activity, but it was still a necessary and critical part of their experience at the stable. By working hard and taking on challenges, the girls did what was needed for the horses and in doing so, built competence. It helped them to develop an ability to make assessments, handle difficult situations, and develop a preparedness to take action and demonstrate initiative. It was also a way to acquire skills in order to potentially work professionally with horses. The final aspect, friendship among the girls, was not a primary reason for choosing their leisure activity but was an important motivator for continuing to come to the stable. As their friendship evolved, the girls had other women and girls to share experiences with who had the same or similar interests. The girls also became role models for each other - showing that young females can accomplish almost anything. This fellowship was also an important aspect of their collective identity process, allowing them to resist wider expectations about how to look and be. The stable was a safe place where they knew how to meet the gaze of the others and how to perform, for they had control (cf. James, 2001).

In line with Butler's theory of identity creation (Butler, 1999), the way the girls act and make active choices regarding subject positions available to them, directs the way they formulate their identities. In this leisure environment, the girls were able to position themselves in ways at odds with the gender stereotypes in their wider society. Their way of enacting gender through the encounter with the horse and the physical work at the stable, differed from what they experienced in other surroundings. The stable can be seen as a restricted zone, comparable to the privacy of a bedroom (James, 2001), where the girls get a break from the traditional heterosexual interplay in the surrounding society. The girls were aware of and accepted heterosexual norms, but they refused to fully adapt to them. They viewed themselves as being tough and competent, as persons who would not hesitate to act, though faced with obstacles, and who embrace the opportunities that emerge. 
According to Butler's (2004) research, identities maintain order within situated practices and it is important for researchers informed by social constructivist perspectives to find social systems within which the obvious gender pattern is challenged. The stable seems to be such a place since it is dominated by women and girls. However, norms and structures of the riding schools have a masculine history, as the stables in Sweden originate from the cavalry and former military use of horses. Male concepts such as hierarchy, orderliness and discipline are still fundamental aspects of riding (Raber \& Tucker, 2005). The girls have to relate to these aspects. At the stable, the girls were prepared and had the courage to face critical situations - to develop "masculine" as well as "feminine" traits.

With regard to Henderson and Hickerson's (2007) call for leisure research that focuses on what meaning girls experience in the activities in which they invest, we have explored the meaning of horse riding to adolescent girls. The notion that spaces such as the stable offer a learning process to develop young girls' identities in non-subordinate ways invites more research on this subject. As Swedish riding schools are supported by the government, riding is less class-bound than in many other Western countries. If our results are robust and can be replicated, then the riding school may function as a strong development site for young girls, and policy makers in other countries might consider whether subsidising riding may be a way to promote development, both in terms of gender equality and on a psycho-social level. It does seem that the competences learnt at the stable are competences that are linked to personal and societal growth.

As we have studied only six girls at one riding stable in Sweden, the question arises: to what extent can the result be generalised? The methods we used were directed to the girls' own experiences at the stable (see Skeggs, 1997). Put in a theoretical context, what the girls told us and what we observed can add to our understanding of teenage girls' opportunities to choose their ways of performing gender and what it means for them. While the specifics of other, different, riding schools may lead to some variation in responses, our conclusion remains that, using a social constructivist approach, informed by Butler's work, we have added to an understanding of the way gender is constructed in social spaces which provide freedom from everyday, heterosexist, signals about how "girls" become "women".

\section{References}

Ambjörnsson, F. (2004). I en klass för sig: Genus, klass och sexualitet bland gymnasietjejer [In a class by itself: Gender, class and sexuality among school girls]. Stockholm, Sweden: Ordfront förlag.

Auster, C.J. (2001). Transcending potential antecedent leisure constraints: The case of women motorcycle operators. Journal of Leisure Research, 33, 272-298.

Bäckström, ̊̊. (2005). Spår: Om brädkultur, informella lärprocesser och identitet [Traces: On board culture, informal learning processes and identity]. Studies in Educational Sciences, 74. Stockholm, Sweden: HLS förlag.

Butler, J. (1999). Gender trouble: Feminism and the subversion of identity. New York, NY: Routledge.

Butler, J. (2004). Undoing gender. New York, NY: Routledge.

Crawford, D., \& Godbey, G. (1987). Reconceptualising barriers to family leisure. Leisure Sciences, 9, 119-127.

Deem, R. (1986). All work and no play? A study of women and leisure. Milton Keynes, UK: Open University Press. 
Engström, L.-M. (1999). Idrott som social markör [Sports as a social marker]. Stockholm, Sweden: HLS förlag.

Fook, J., Hawthorne, S., \& Klein, R. (2004). Horse dreams: The meaning of horses in women's lives. North Melbourne, Australia: Spinifex Press.

Forsberg, L., \& Tebelius, U. (2005, June). Horse riding as a leisure activity - a historical review. Paper presented at the first conference of Lifestyle, Health and Technology, Luleå University of Technology, Luleå, Sweden.

Freysinger, V.J., \& Flannery, D. (1992). Women's leisure: Affiliation, self-determination, empowerment and resistance? Loisir et société/Society and Leisure, 15(1), 303-322.

Gilligan, C. (1982). In a different voice: Psychological theory and women's development. Cambridge, MA: Harvard University Press.

Gilligan, C., Lyons, N.P., \& Hanmer, T.J. (1990). Making connections: The relational world of adolescent girls at Emma Willard School. Cambridge, MA: Harvard University Press.

Gordon, R.D. (2002). Conceptualizing leadership with respect to its historical-contextual antecents to power. Leadership Quarterly, 13(2), 151-167.

Hendersen, K. (1989). A leisure of one's own: A feminist perspective on women's leisure. State College, PA: Venture Publishing.

Henderson, K., \& Bialeschki, M. (1993). Negotiating constraints to women's physical recreation. Loisir et SociétélSociety and Leisure, 16, 389-412.

Henderson, K.A., \& Hickerson, B. (2007). Research update: Women and recreation opportunities. Journal of Park and Recreation Administration, 42(4), 26-29.

Jackson, E. (1993). Recognising patterns of leisure constraints: Results from alternative analyses. Journal of Leisure Research, 22, 55-70.

James, K. (2001). "I just gotta have my own space!" The bedroom as a leisure site for adolescent girls. Journal of Leisure Research, 33(1), 71-90.

Kallioniemei, A. (1997). Mikä saa tytöt talleille [The girl on her way to the stable]. Helsinki, Finland: Helsinki University, Pedagogic Faculty.

Kanter, R. (1977). Men and women of the corporation. New York, NY: Basic Books.

Kohlbacher, F. (2006). The use of qualitative content analysis in case study research. Qualitative Social Research, 7(1), Article 21.

Lareau, A. (2003). Unequal childhoods: Class, race and family life. Berkeley: University of California Press.

Larsson, J. (2006). Vem sätter sin kille i ridskola? [Who wants to put his/her son in a riding school?] (Unpublished Master's thesis). Lund University, Lund.

Liljestolpe, C. (2009, October). The horse industry in Europe of today. Paper presented at the EU Equus conference, Uppsala, Sweden.

Lindström, L. (2006). Fritidssektorn - En statlig utmaning [The leisure sector - a governmental challenge] (Licentiate thesis). Luleå University of Technology, Sweden.

Lindström, L. (2009). Leisure activities and youth citizenship: What local councils tell about youth leisure from the perspective of citizenship on their home pages (Unpublished doctoral thesis). Department of Education, Luleå University of Technology, Sweden.

Little, D. (2002). Women and adventure recreation: Reconstructing leisure constraints and adventure experiences to negotiate continuing participation. Journal of Leisure Research, 34(2), 157-177.

Mayring, P. (2000). Qualitative Inhaltsanalyse [Qualitative content analysis]. Weinheim, Germany: Deutscher Studien Verlag.

McRobbie, A., \& Garbor, J. (1976). Girls and subcultures. In S. Hall \& T. Jefferson (Eds.), Resistance through rituals: Youth subculture in post-war Britain (pp. 209-222). London: Hutchinson University Library.

Murray, D., \& Howat, G. (2009). The "enrichment hypothesis" as an explanation of women's participation in rugby. Annals of Leisure Research, 12(1), 65-82.

Nikku, N. (2005). Stallkulturen som arena för flickors identitetsskapande [The stable culture as an arena for girls' identity creating]. Sociologisk forskning, 4, 29-34.

Park, R., \& Wright, J. (2000). Through their eyes: An investigation into the physical activity needs and interests of young women. ACHPER Healthy Lifestyles Journal, 47(3/4), 15-20.

Raber, K., \& Tucker, T.J. (2005). The culture of the horse: Status, discipline, and identity in the early modern world. Basingstoke, UK: Palgrave Macmillan. 
Redelius, K. (2002). Ledarna och barnidrotten: Idrottsledarnas syn på idrott, barn och fostran [The leaders and children's sports: Sports leaders' views on sports, children and education] (Doctoral thesis). Studies in Educational Sciences, No. 55, Stockholm University.

Rostgård, L. (2002). Mestring og melodrama - piger og heste, I Sørensen, A.C. (red) Pier, pink og power - om aktuel pigekultur [Girls, pink, and power - on contemporary girl culture]. Köpenhamn, Sweden: Gads Forlag.

Skeggs, B. (1997). Formations of class and gender: Becoming respectable. London: Sage.

Ståhlberg, U. (1999). Den svenska ridskolan 50 år 1948-1998 [The Swedish riding school 50 year anniversary 1948-1998]. Unpublished paper.

Statens offentliga utredning (SOU). (2000). En svensk hästpolitik [A Swedish horse policy]. Stockholm, Sweden: Fritzes förlag.

Stern, D.N., \& Ammaniti, M. (1994). Psychoanalysis and development: Representations and narratives. New York: New York University Press.

Tebelius, U. (1999). Självtillit eller prestationsångest: Idrottandets betydelse för unga kvinnor under tonåren [Self-efficacy or performance anxiety: The meaning of sports to young women during youth time]. Svensk Idrott, 3, 8-14.

Tebelius, U. (2001). Girls' involvement in sport: Dynamics of sport participation of 12-19 year old female athletes. Kinanthropologica, 37(2), 67-80.

Tebelius, U. (2009). The significance of sport participation for teenage girls' self-image. Kinanthropologica, 45(1), 131-142.

Tolonen, T.-R. (1992). Hevoset ja mina: tyttökulttuuri ratsastustallilla [The horse and me: Girls' culture and riding]. Helsinki, Sweden: Helsinki University, Department of Sociology.

Weiss, G. (1999). Body images: Embodiment as intercorporeality. New York, NY: Routledge.

Winter-Jorgensen, M., \& Philips, L. (1999). Diskursanalyse som teori og metode [Discourse analysis as theory and method]. Frederiksberg, Denmark: Roskildes Universitetsforlag.

Wright, J., Brown, R., Muir, P., Rossi, T., Tinning, R., \& Zilm, T. (1998). Parents' and teachers' perspectives of children's and young people's participation in physical activity. Report for the Department of Health and Aged Care, University of Wollongong, Australia. 